\title{
Studies on Isotactic Polyvinyl Alcohol
}

\section{Acetylation of Polyvinyl Benzyl Ether with Acetic Anhydride and Stannic Chloride}

\author{
By Kiyoshi Fujii*
}

In order to obtain isotactic polyvinyl esters, acylation of polyvinyl ether (presumably isotactic) using an organic acid anhydride and a Lewis acid was tried. Vinyl benzyl ether which has a cleavable ether bond, was chosen as a monomer and synthesized by the Reppe process. White nontacky crystallizable polyether was obtained in a low temperature polyphase polymerization following Murahashi's method using trifluoroboron etherate as a catalyst. Acetylation product of the polymer with acetic anhydride and stannic chloride was soluble in methanol and acetone unlike the original polyvinyl ether. From Infrared spectrum study and analytical results on the product, it was recognized that substitution of the benzyl ether group to acetate group proceeded almost completely. X-ray pattern and infrared spectrum of the polyvinyl acetate obtained agreeded well with those of ordinary polyvinyl acetate obtained by free radical polymerization, where no sign of crystallinity was observed.

The acetylated polymer was hydrolyzed in sodium hydroxide methanolic solution. The hydrolyzed polymer was soluble in water. Its degree of polymerization was estimated to be about 500 from viscosity measurement of aqueous solution.

第 2 報 アイソタクチックポリギ酸ビニルの合成

(1961 年9月 4 日受理)

藤井 洌**. 望月隆仁**

\begin{abstract}
要旨 ビニル tertーブチルエーテルから結晶性および非晶性の 2 種類のポリマーを得た。これらを無 水酢酸上四塩化スズあるいは塩化垔鉛で処理してア七チル化した後にアルカリケン化してポリビニルアルコー ルとし，さらにギ酸エステル化した。生成ポリマーはポリギ酸ビニルであることが確認された。結晶性ポリマ 一を原料とするものは鋭い結晶性のX線反射を示し, 延伸試料㳉 6.55 A の繊維周期を与えた。一方, 非晶性 のポリマーから得たものは通常の高温ラジカル重合により得られるポリキ酸ビニルと同様に非晶性の八ローを 与えた。

以前にわれわ机は低温ラジカル重合により得たポリキ酸ビニルは,くり返し周期 $5.0 \AA$ の繊維図形を与える ことを見出したが，本実験の結果から以前に得た結晶性ポりキ酸ビニルはシンジオタクチック構造をもつこと が確铝された。このようにしてビニルエステルでは, 初めてアイソタクチックおよびシンジオタクチック樓造 の二つの結晶性ポリマーボ得られ，X線的に明らかにされた。

アイソタクチックポリキ酸ビニルの延伸試料を不均一系でアルカリケン化して得たポリビニルアルコールは 在来のポリピニルアルコールと同様な綞維図形を与え、くり返し周期は $2.5 \mathrm{~A}$ であった。
\end{abstract}

\section{1. 緒言}

ポリビニルアルコール (PVA) の側鎖水酸基の立体配 㯰については，近年種々の角度から検討されている。 Haas ら" は三フッ化酢酸ピニルが通常のラジカル重合 によっても結晶性ポリマーを与えること, ポリ三フッ化
酢酸ビニル (PVTA) をケン化して得られるPVAが熱水 にも溶けがたいこ上を見出した。PVTA はくり返し周 期 $4.8 \AA$ の繊維図形を与えるがそれから得られる PVA は在来のPVA と同様に $2.5 \AA$ P り返し周期を示す。 その後の検討によれば, PVTA は規則性に富んだ構造 をむつ PVAを与えることが確認された2!。しかし一方

* Research Laboratory, Kurashiki Rayon Co., (Sakazu, Kurashiki, Okayama)

** 合数レイヨン株式会社研究所 (岡山県倉数市酒津) 
では PVTA の繊維写真はくり返し周期を $4.8 \AA$ として シンジオタクチック構造を想定しても他の反射をすべて 満足に説明できぬことが明らかにされ8),4)，また酷酸ビ ニルから得られる在来の PVAをエステル化してつくっ たPVTA も同様な結晶性反射を与えることも認められ 問題を複雑にしている。

われわれはさきにギ酸ビニルの低温重合物が結晶化し らることを見出した。繊維周期は $5.0 \AA$ でシンジオタク チックな構造が考えられた。また他のビニルエステルよ りえられる PVA をギ酸エステル化して調べるといずれ も低温重合物より得たものはより結晶化しやすいことが 認められ, 同時にモノマー構造の立体特異性への影響も 明らかにされた ${ }^{6)}$ 。PVA の立体特異性については，そ の低分子モデルの立体異性体の赤外吸收 ${ }^{7)}$ や PVA のア セタール化物の溶液中にお汁る広がり ${ }^{8-1)}$ や双極子モー メント ${ }^{8-2)}$ の研究が行なわれている。ギ酸ビニルから得 られる PVA についてもアセタール化物の広がりを調べ たが、ギ酸ビニルは他のビニルエステルとは全く特異な 挙動を示すことが見出された ${ }^{9)}$ 。

前報でポリビニルベンジルエーテルのアセチル化反応 によってアイソタクチックなPVA を合成しようとする 試みについて述へた。最近さらに原料ポリマーの合成方 法の改良や11,12), アインタクチックPVAの主として赤 外吸収による研究 ${ }^{13)}$ が発表された。われわれはべンジ ルエーテルから得られる PVA はやや重合度が低いと考 えたのでこの点を改良すべくまたよりェーテル結合の切 断を完全にし，かつアインタクチック構造に富んだ試料 をつくる目的でビニル tert-ブチルエーテル (VtBE) を 原料とする方法を検討した。

われわれはポリギ酸ビニル(PVF)の $\mathrm{X}$ 線回折につい て詳しく調べており，その一部はすでに報告したが， PVF ではその結晶性と立体特異性の関係が非常に密接 であることが特色である゙,14。 。イソタクチックな構造 をもつPVFが X 線的にどのような挙動を示すかは興味 ある問題であり、これがわれわれの本研究に著手した理 由である。

\section{2. 実験}

\section{1 試料}

$\mathrm{VtBE}$ 当所で合成したものを使用した（沸点 $77.0-$ $78.5^{\circ} \mathrm{C}$, 届折率 $1.3990\left[20^{\circ} \mathrm{C}\right]$ )。

トリエチルアルミニウム 市販品をそのまま使用し た。

塩化亜鉛 市販の特級品をそのまま使用した。

キ酸 Merck 社製 $(98$ 100\%) のものを使用した。 その他の触媒や溶剤は市販品を常法に上り特に脱水に 留意して精製したものを使用した。

2.2 重合
以下重合例を示す。

\section{2.1. (No. TB-X-4)}

$\mathrm{VtBE} 10 \mathrm{~m} l$ とトルェン $35 \mathrm{ml}$ を混合して $-78^{\circ} \mathrm{C}$ に冷 却し, トリエチルアルミニウム $0.0266 \mathrm{~g}$ と四塩化チ夕 ン $0.021 \mathrm{~m} l$ を窒素下 $0^{\circ} \mathrm{C}$ に保った $n$-へキサン $5 \mathrm{ml}$ に 加えて調製した触媒溶液と上記のモノマー溶液を混合 し， $-78^{\circ} \mathrm{C}$ にて 24 時間重合せしめた。メタノール中に 反応混合物を投じてポリマーを沈殿させ, ベンゼンに溶 かしメタノール中に沈殿させる操作をくり返した後, 減 圧乾燥して $4.2 \mathrm{~g}$ のポリマーを得た。 $30^{\circ} \mathrm{C}$, ベンゼン中 の極限粘度数は 176 であった。この白色粉末ポリマーの X線図には面間隔 $10.2,6.7$ および $5.5 \AA$ に相当する 位置に反射が認められ, 若干の結晶性の存在が確かめら 札た。これらは岡村らが報告しているところとよく一致 した結果である。

\subsection{2. (No. TB-X-9)}

$\mathrm{VtBE} 5 \mathrm{~m} l$ と臭化エチル $20 \mathrm{ml}$ を混ぜー $50^{\circ} \mathrm{C}$ に保ち, 四塩化スズ $0.0253 \mathrm{~g}$ を加え 4 時間重合させた。収量 $2.6 \mathrm{~g}$, 極限粘度数 18 であった。

2.3 ポリヒニル tert-プチルエーテル (PVtBE) の アセチル化反㐫

ベンジルェーテルの場合に準じて行なった。一例を示 す。

PVtBE $2 \mathrm{~g}$ をベンゼン $10 \mathrm{~m} l$ に溶かし, さらにベン ゼン $10 \mathrm{~m} l$ と無水酢酸 $10 \mathrm{~m} l$ の混合液を加えてポリマ 一溶液を作成した。塩化带鉛 $0.8 \mathrm{~g}$ を無水酶酸 $5 \mathrm{~m} l$ へ ンゼン $10 \mathrm{~m} l$ の混合液に溶かした触媒溶液を室温下ポリ マー溶液中に強くかきまぜを行ないつつ加えた。系は直 ちに暗緑色に着色しゲル化した。ゲルを取り出してベン ゼンに溶かし $n$-へキサンに沈殿させる操作をくり返し て後乾燥した。このポリマーをベンゼン $20 \mathrm{ml}$ と無水酢 酸 $10 \mathrm{ml}$ の混合液に溶かし, 四塩化スズ $0.8 \mathrm{~g}$, ベンゼ ン $5 \mathrm{~m} l$ および無水䣷酸 $5 \mathrm{~m} l$ の混合液を加えた。この系 では不均一化は起らずに反応は均一系で進行した。 5 分 後に反応を停止し, 前報 ${ }^{10)}$ と同様の操作でポリマーを精 製単離した。わずかに黄色を帯びた白色のポリマー $1.4 \mathrm{~g}$ が得られた。この赤外吸収は通常のポリ酶酸ビニル とよく一致しているが, 水酸基によると考えられる $3 \mu$ 付近の吸収も若干認められた。このポリマーを常法によ りメタノール中にてアルカリケン化して PVA とした。

\subsection{PVA のギ酸エステル化}

PVA を無水のギ酸で処理してェステル化し，100\% エステル化するまで反応をくり返し行なった。エステル 化物の赤外吸収, ケン化価および元素分析による検討の 結果はいずれも生成物が PVFであることを示してい る。Table 1 に原料 PVtBE，ギ酸エステル化物および ラジカル重合により得た PVF の元素分析值をそれぞれ 示した。アルカリ消費量 (エステル洒)から No. TB-X-4 
Table 1. Analitical results of the polymers.

\begin{tabular}{|c|c|c|c|c|c|c|}
\hline \multirow{2}{*}{ Sample No. } & \multirow{2}{*}{ Material } & \multirow{2}{*}{ Structure } & \multicolumn{2}{|c|}{ Calculated } & \multicolumn{2}{|c|}{ Observed } \\
\hline & & & C, $\%$ & $\mathrm{H}, \quad \%$ & C, $\%$ & $\mathrm{H}, \quad \%$ \\
\hline TB-X-1 & $\begin{array}{l}\text { Polyvinyl tert-butyl } \\
\text { ether (PVtBE) }\end{array}$ & $\left(\mathrm{C}_{6} \mathrm{H}_{12} \mathrm{O}\right)_{n}$ & 71.94 & 12.08 & 72.25 & 12.09 \\
\hline F-TB-X-4 & $\begin{array}{l}\text { Polyvinyl formate } \\
\text { derived from PVtBE }\end{array}$ & $\begin{array}{l}\text { presumably } \\
\left(\mathrm{C}_{8} \mathrm{H}_{4} \mathrm{O}_{2}\right)_{n}\end{array}$ & 50.00 & 5.68 & 49.79 & 5.20 \\
\hline VF286 & $\begin{array}{l}\text { Ordinary polyvinyl } \\
\text { formate }\end{array}$ & $\left(\mathrm{C}_{3} \mathrm{H}_{4} \mathrm{O}_{2}\right)_{n}$ & 50.00 & 5.68 & 49.90 & 5.64 \\
\hline
\end{tabular}

のエステル化度は $99.4 \%$ と計算された。 No. TB-X-9 は量が少ないので調べられなかった。

\section{5 赤外線吸収スペクトル}

Perkin-Elmer 112 型および島津製自記赤外分光光度 計 IR-27 型を用いた。ポリマー試料のアセチル化物は ア七トン，またPVF はギ酸の各溶液からそれぞれ厚さ 10-20 $\mu$ の皮膜を作成して測定に供した。

\section{$2.6 \mathrm{X}$ 線回折}

\subsection{1. 回折写真}

ニッヶルハクでロ光した銅の示性 $\mathrm{X}$ 線 $(35 \mathrm{kV})$ を用い た。試料は厚さ約 $0.2 \mathrm{~mm}$ の皮膜とし円孔細隙を用い て平板カセット(試料一フィルム間距離 $5.0 \mathrm{~cm}$ ) で撮影 した。

\subsection{2. $\mathrm{X}$ 線デフラクトメーター}

島津製 $\mathrm{X}$ 線デフラクトメーターを用い透過法により 測定した。

\section{3. 結果および考察}

Table 1 に示したギ酸エステル化物の元素分析值およ びアルカリ消費量よりエステル化反応が完全に行なわれ ていることが示されたが赤外吸収スペクトルもまたこの 結果を支持している。Fig 1 に二つのエステル化により 得た PVF とラジカル重合により得た PVF のスペクト ル図を比較して示した。3 者はいずれもよく似た吸收を 示す。特に No. TB-X-9 はラジカル重合物と结とんど 一致したスペクトル困を与えている。No. TB-X-4 は若

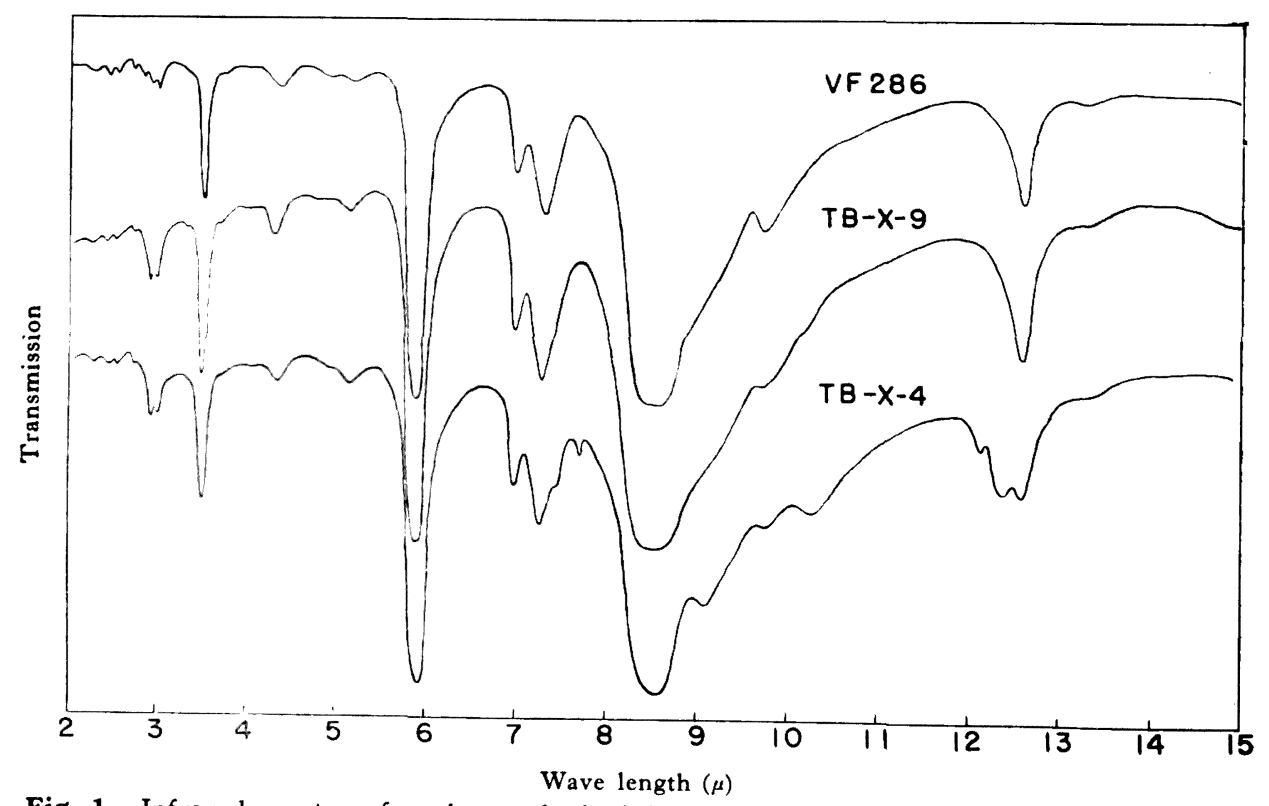

Fig. 1. Infrared spectra of various polyvinyl formates (PVF). No. VF 286 is ordinary PVF prepared by free radical polymerization of vinyl formate at $30^{\circ} \mathrm{C}$, No. TB-X-9 is derived from noncrystallizable polyvinyl tert-butyl ether (presumably atactic) and No. TB-X-4 is derived from crystallizable polyvinyl tert-butyl ether (presumably isotactic). 


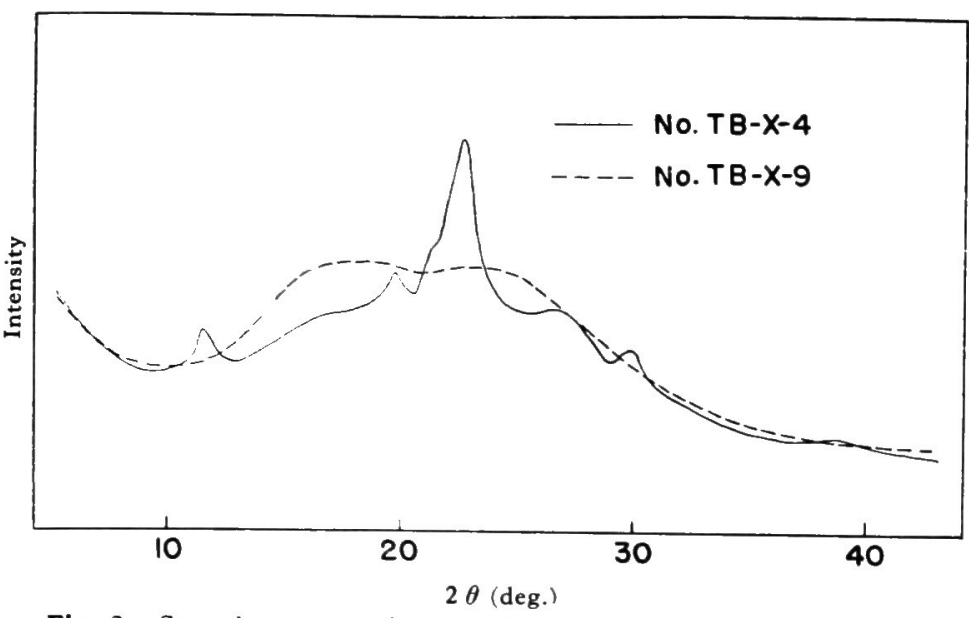

Fig. 2. Scanning curves for polyvinyl formates derived from crystallizable (No.TB-X-4) and noncrystallizable polyvinyl tert-butyl ethers (No. TB-X-9).

干吸收が異なる点もあるが, 新たに出現した吸收帯はェ ステル化する前に原料 PVA にも認められなかったもの であり化学的な異種結合によるものでないことは明らか である。この差異はむしろ PVF の立体特異性の差に基 くものと考えられ, さらに詳しい検討により No. TB-X -4に見られる新し、吸収はアイソタクチック PVFに特 有な結晶性バンドであることが認められた。これについ ては後報で詳しく報告する。以上の結果, 得られたポリ マーが PVF であることが明らかとなった。

2 種類の PVF のX 線回折を調へた。両者の間には著 しい差が認められた。すなわちアタクチックな構造を持

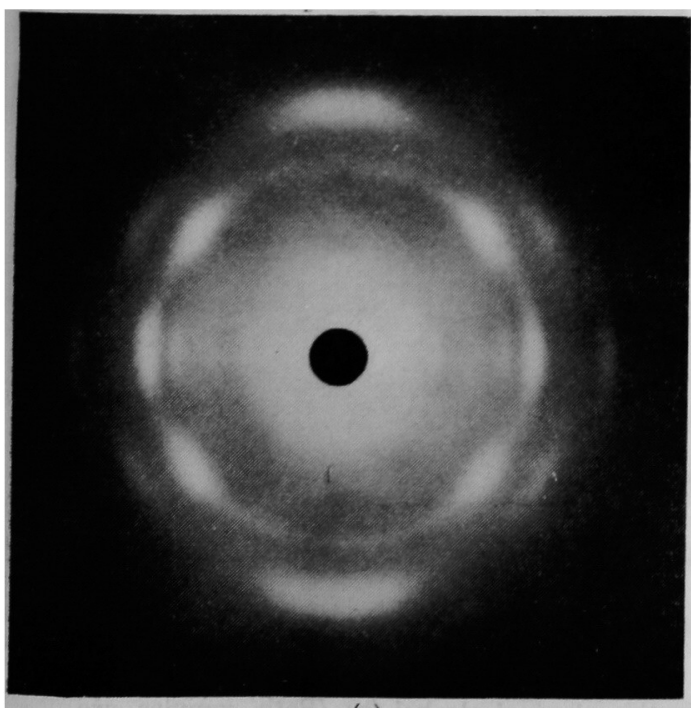

(a)

Fig. 3. Fiber patterns of isotactic
つと考えられる(No. TB-X-9) は通 常の高温ラジカル重合により得た PVF と同様に2本のハローを与える のみであるが, アイソタクチックな 構造を持つと考えられる (No.TB-X 一4)は鋭い結晶性の反射を与えた。 Fig.2に両者の走査曲線を示したが, (No.TB-X-4) の反射の位置はさき に見出された低温ラジカル重合物の 結晶性の反射とは全く異なってい る。Fig. 3 にそれを繊維写真で示し た。延伸試料はよく配向して美しい 繊維図形を与え, くり返し周期は $6.55 \AA$ である。纎維写真の各反射 は六方晶系として指数付けが可能で あり, $a=b=15.9 \AA, c=6.55 \AA$ なる単位格子が与えられ格子中に 18 個の基本体が入っていると考えると 計算密度は 1.49 で実測密度 1.358 と比較して妥当な值

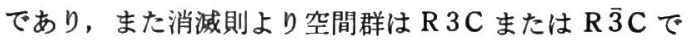
あることなどが認められており, これの事実から (No. TB-X-4) は 3 回ラセンのアイソタクチック構造を持つ ことが明らかとなった。詳しい構造解析の結果は次報に 譲ってここでは省略する。以上の結果から，さきに得た くり返し周期 $5.0 \AA$ を示す PVF はシンジオタクチック 構造を持つことが明確に結論され，ここに得たアイソタ クチック構造を持つPVF とあわせてポリピニルエステ ルでは初めて 2 種類の立体特異性ポリマーが $\mathrm{X}$ 線的に 確羿されたことになる。今までに同一のモノマーから 2

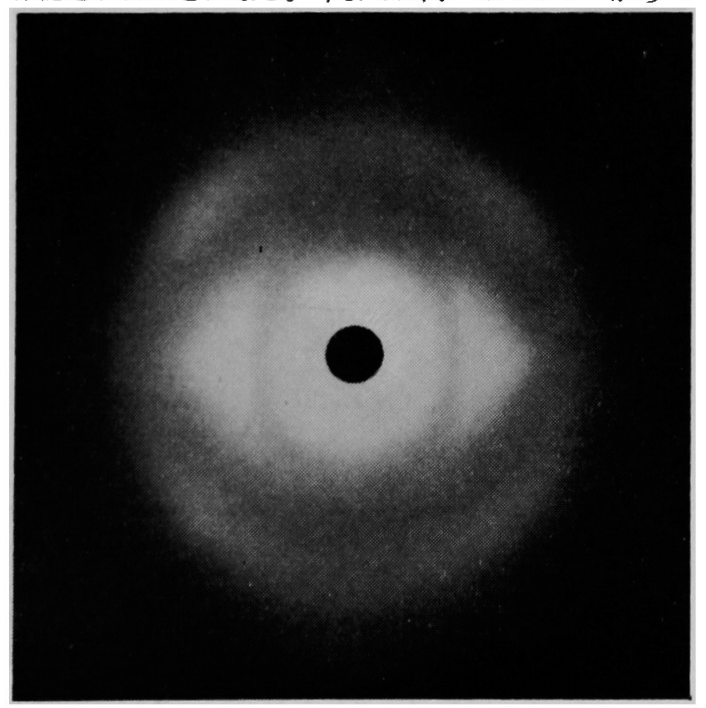

(b)

and syndiotactic polyvinyl formate (b). 
種類の立体特異性ポリマーがともに合成され確認されて いる例はきわめて少数例であって，われわれの知るかぎ

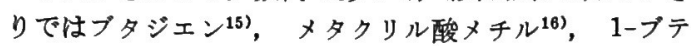
ン17) およびプロピレン17) の4 例がある。

以上の結果は今までいろいろと議論されて来た通常の ポリビニルェステルの立体特異性を明らかにする重要な 一手段を与えることになる。酶酸ビニルから得られる PVAをエステル化してPVFとして調べると非常に結晶 性は乏しいが低温重合物を原料とするものは, より低温 で重合したものほどしだいに Fig 3-b に似た写真を与え るような傾向がある。また PVTA を原料とする PVF は $+60^{\circ} \mathrm{C}$ 重合物でもほぼギ酸ビニルの $-40^{\circ} \mathrm{C}$ 重合物に相 当する結晶性を示す日)。このようにピニルェステルのラ ジカル重合物はモノマーの構造によりそれぞれ異なった 立体特異性を持つが, どちらかといえばアタクチックな 構造を有し重合温度が低くなるほどシンジオタクチック 構造が増してくることが明らかになった。この問題につ いて今までに種々の角度から論ぜられており, 問題が明 らかとなった現在さらに検討を続けるべき重要な点が残 されているがそれは別の機会に論じたい。

アインタクチック PVF の延伸試料をアルカリ性メタ ノール中に漫漬して皮膜の形態を保ったままケン化して PVA となし, そのX線回折写真を撮影した。Fig 4 にそ れを示したが， PVA に特徴的な (100)，(101)，(200),

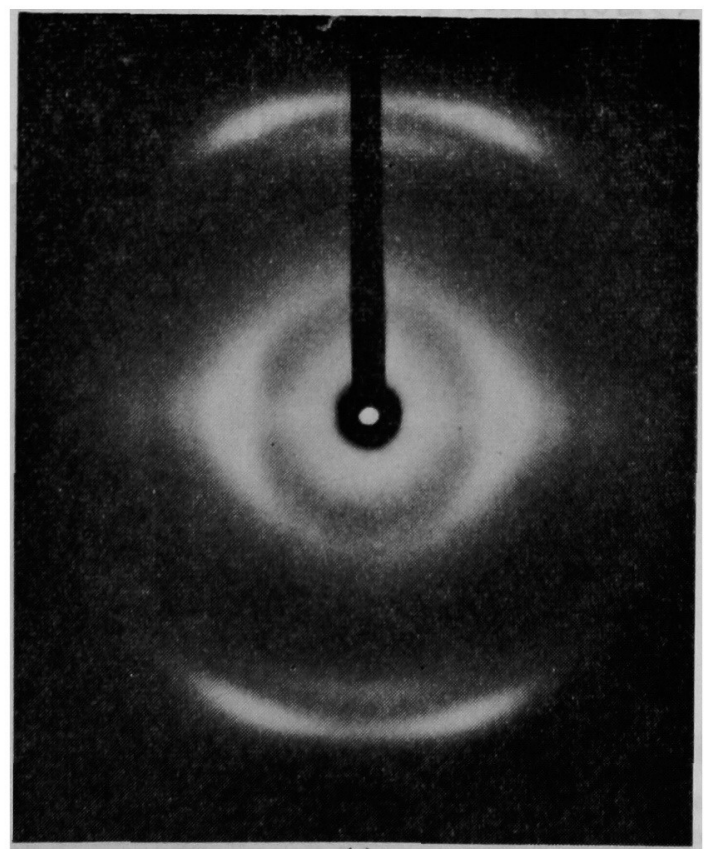

(a)
（111）などの反射の強度的関係およで面間隔は全く徉来 のものに一致している。もちろんくり返し周期は $2.5 \AA$ で差が認められない。微細構造に関する差異については なお研究すべき点があるが,ここに得た結果に関する限 りまず同じ輩造を考えざるをえない。逆にいえば PVA の立体特異性はX線図では区別することが困難である。 しかしこの PVA の熱に対する举動は従来のものとは全 く異なっていることが認められた。この実験結果につい ては第 4 報で詳しく報告する予定である。上述したよう に立体特異性の問題は明らかにされたわけであるが, 完 全にアイソタクチックな PVA がどのような結晶性を示 すか, またアタクチックな箠造に比ベてシンジオタクチ ック部分の結晶に対する寄与の差などの点は今後さらに 検討を要する問題である。

最近岡村ら ${ }^{12)}$ はかれらの得た結晶性の PVtBE の繊維 周期は $6.8 \AA$ でありアイソタクチック構造が推論される ことを報告している。われわれの得たポリマーも同様の 反射を与えるので同じ構造を有していると考えられる。 したがって PVtBE はアインタクチック構造を持ってお り,しかも，アセチル化，ケン化，ついでギ酸エステル 化の 3 種の反応を通じて立体特異性が保持されたことに なる。またポリ酢酸ビニル，PVA の形ではX線回折あ るいは赤外吸収によって立体特異性は容易に知りえない といえよう。

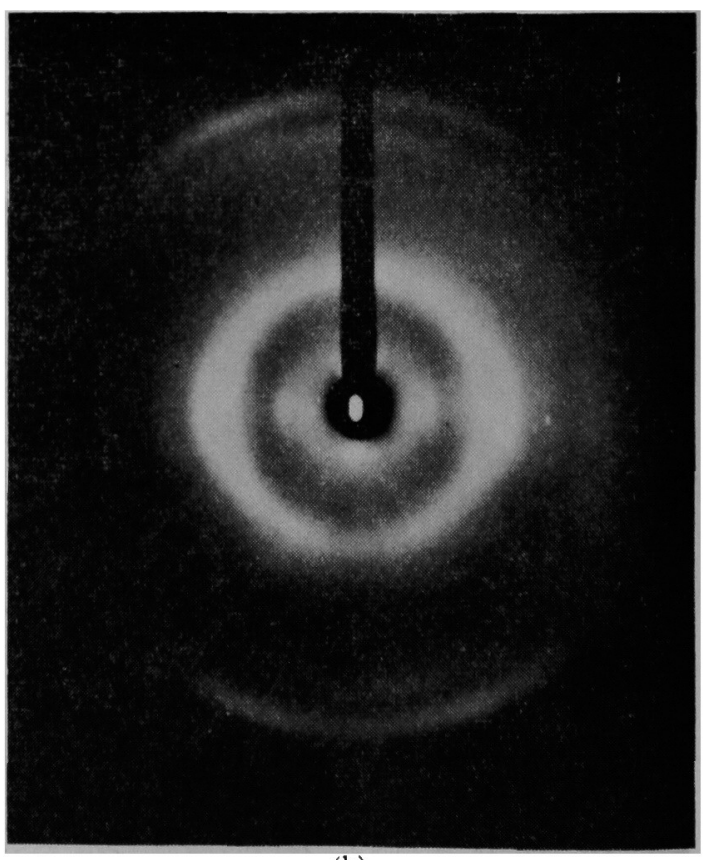

(b)

Fig. 4. Fiber patterns of isotactic (a) and syndiotactic polyvinyl alcohol (b). (Both samples are hydrolyzed heterogeneously in stretched form). 
対照試料として作成したアタクチック PVF (No. TBX-9） は特に乱れた構造を与えるような重合条件により 得た PVtBEを原料とした。重合条件としては第 1 にビ ニルエーテルの重合において立体規則性の乏しいポリマ 一を与える四塩化スズを解媒とし, 第 2 により高い重合 温度を用いさらに第 3 に透電率の大きい溶剤を選んで重 合した。この結果, 重合度はかなり低くなったが,この 程度の重合度では結晶性の問題を調へるのに著しく影響 することはないと考えられる。この PVtBE は若干粘着 性を有する粉末で $\mathrm{X}$ 線的にも非晶性であることが認めら れた。チーグラー型触媒によるビニルェーテルの立体特 異性重合18)についてはよく知られており，この方法で 得たポリマーから誘導したPVF と他の方法で得たもの からの PVF とを比較検討することも興味ある問題であ るが,これについては後報にゆずる。アインタクチック PVF についての X 線回折および赤外吸収の研究の詳細 は別にとりまとめて報告する予定である。

\section{4. 結言}

以上, 結晶性の PVtBE より誘導したPVFがX線的に も明睹にアイソタクチック構造を示す事実を見出しギ 酸ビニルのラジカル重合より得た知見とあわせて PVA の立体特異性の問題を明らかにしえた。今までにこの問 題について明確な結論を導きえなかったのは，側鎖の小 さいといら特徴を有する PVA と立体特異性にかかわら ず結晶化しないその酢酸エステルとの関連において問題 を論じていた点にあろう。

付 記: PVtBE のアセチル化反応については, 最近岡村 ら ${ }^{12)}$ の詳しい検討結果が発表された。それによると四塩化ス ズ以外のルイス酸の方が反応を内滑に進行せしめるには良いと のことである。われわれはベンジルエーテルに対してと同椂に 四㨁化スズないしは塩化亜㫟を使用したが，PVtBE では反応 中にゲル化が起こることを認めた。この原因は不明であるが， 反店を 2 回くり返せばアセチル化はほほ完全に行ないえた。こ の研究では生成物のキ酸エステルが目的であったのでアセチル 化反応については詳しい検討は省略した。

終始ご指導ご㯖達を賜わった当所松本昌一博士，浮田純二博 士および井本三郎氏に厚く感即する。またビニルエーテルの重 合について種々ご教示いただ、た当所㮞田洋氏に厚く感即す る。また発表を許可された会社当局に感謝する。

\section{文献}

1) H. C. Haas, E. S. Eerson and N. W. Schuler : J. Polymer Sci., 22, 219(1956)

2) 伊藤泰輔, 野間夫之, 桜田一郎：高化, 16, 115 (1959)

3）茶谷陽三, 田口稲男, 左納武蔵, 滝沢武夫：繊維 科学研究所年報, 第 13 号, 37(1960)

4) 桜田一郎, 伊藤泰輔: 私信

5) 藤井洌, 望月隆仁, 井本三郎, 浮田純二, 松本 昌一：高分子討論会 (昭 35 年 11 月京都) で発表, 高化投稿予定

6)藤井洌, 望月隆仁: 未発表, 高化投稿予定。文 献 9)に引用さる。

7) たとえば 長井栄一：高分子展望, 第 15 集, 40 (1959)

8-1）たとえば 松本昌一: 高分子展望, 第 15 集, 21 (1959)

8-2）今村喜夫：日化, 82, 979(1961)

9) 藤井 洌, 大柳康治, 井本三郎, 浮田純二, 松本 昌一：高分子討論会 (昭 35 年 11 月, 京都) にて発 表, 高化投稿予定

10）藤 井 洌：高分子研究発表会 (昭 35 年 6 月, 神戸) にて発表。高化, 投稿中

11）村橋俊介, 結城平明, 米村有民: 第 10 回高分子年 次大会（昭 36 年, 5 月, 東京) にて発表

12）岡村誠三, 東村敏延, 児玉恒雄: 第 10 回高分子年 次大会（昭 36 年, 5 月, 東京) にて発表

13）村橋俊介, 結城平明, 田所宏行, 茶谷陽三, 米村 有民, 福田 健, 筒井正夫：第 10 回高分子年次大 会 (昭 36 年, 5 月, 東京) にて発表

14) 藤 井 洌, 井本三郎, 浮田純二, 松本昌一：高分 子討論会（昭 35 年, 京都) にて発表, 高化投稿予 定。

15) G. Natta: Chim. c Ind (Milano), 38, 751 (1956)

16) T. G Fox, B. S. Garrett, W. E. Goode, S. Gratch, J. F. Kincaid, A. Spell and J. D. Stroup: J. Am. Chem. Soc., 80, 1768(1958)

17) G. Natta: Makromol. Chem., 35, 94 (1960)

18) G. Natta, G. Dall' Asta, G. Mazzanti, U. Giannini and S. Cesca: Angew. Chem., 71, 205 (1959)

\title{
Studies on Isotactic Polyvinyl Alcohol
}

\author{
II. Synthesis of Isotactic Polyvinyl Formate
}

By Kiyoshi Fujii* and Takani Mochizuki*

Crystallizable and noncrystallizable polymers were prepared from vinyl tert-butyl ether using

\footnotetext{
* Research Laboratory, Kurashiki Rayon Co., (Sakazu, Kurashiki Okayama)
} 
Ziegler catalyst and stannic chloride as initiator respectively. Two types of polyvinyl tertbutyl ethers (PVtBE) were acetylated by means of acetic anhydride and stannic chloride or zinc chloride and then saponified to give polyvinyl alcohol. Two types of polyvinyl alcohol thus obtained were formylated using formic acid. From analytical results and infrared spectra studies on the products, it was shown that the formylation proceeded almost completely resulting to polyvinyl formates (PVF).

PVF derived from crystallizable PVtBE was crystallizable while PVF derived from noncrystallizable PVtBE was noncrystallizable. The crystallizable PVF gave sharp fiber diagram and the repeat distance along the fiber axis was $6.55 \AA$ showing that the regular sequences in the polymer possessed isotactic configuration.

Previously we found that PVF obtained by free radical polymerization at low temperature was crystallizable and supposed the existence of syndiotactic structure from the identity period-5.0 A. Thus isotactic and syndiotactic PVF are prepared and confirmed by $x$-ray examination for the first time. Syndiotactic propagation in the free radical polymerization of vinyl esters is enhanced over isotactic propagation by decreasing polymerization by decreasing polymerization temperature.

Stretched films of isotactic and syndiotactic PVF were subjected to heterogeneous hydrolysis. Both polyvinyl alcohol films obtained gave fiber patterns which resemble each other and the identity period calculated was $2.5 \AA$ in both samples. 